\title{
Impact of Corporate Governance Mechanisms on Firm's Performance: A Study on Listed Conventional Banks
}

\author{
Sumon Kumar Das \\ Lecturer, Department of Business Administration, Noakhali Science and Technology University, Noakhali-3814, BANGLADESH \\ *E-mail for correspondence: $\underline{\text { sumon30du@gmail.com }}$
}

https://doi.org/10.18034/abr.v7i1.6

\begin{abstract}
This study examines the impact of corporate governance mechanisms on firm's performance on listed conventional banking companies at Dhaka Stock Exchange (DSE). Based on existing empirical studies, five key attributes of corporate governance (board size, the proportion of independent directors on board, the proportion of female directors on board, institutional ownership and size of audit committee) have been selected to identify their influence on firm's financial performance. Tobin's Q (a market-based performance measure) and Return on Asset- ROA (an accounting based performance measure) consider as financial performance measures. Using OLS as a method of estimation, the results provide evidence of a significant negative relationship between the performance of the firm and the proportion of independent directors on board as well as size of the audit committee. The result also provides evidence of a significant negative relationship between Tobin's $\mathrm{Q}$ and institutional ownership but a positive and insignificant between ROA and institutional ownership. Furthermore, there is a negative relationship between the proportion of female directors in board and the performance of the firm but is not significant. Board size as predictor variable is negative and insignificant with Tobin's $Q$.
\end{abstract}

JEL Classifications: G 21, G 34

Keywords: Board of Directors, Corporate governance, Firm performance, Tobin's Q, Return on Asset

\section{INTRODUCTION}

The primary goal of a firm is to maximize the wealth of the shareholders. The wealth is created by a firm through its actions and decisions as reflected on its market value. The market value of the firm shares is the reflection of shareholders' perception of the quality of its financial decisions and performance. Therefore managers' actions and decisions should lead to shareholders' wealth maximization. In agency theory, explained the agency relationship arises when one or more persons (the principal) employs another person (agent) to provide a service and then the principal delegates decision-making authority to the agent (Jensen and Meckling, 1976). But for various reasons (i.e. personal self-interest, separation of ownership from management and asymmetry of information between agent and principal) the agent may act for his or her interest even if it is against in the interest of the principal. Berlee and Means (1934) generalized this behavior as that leading to agency cost.
Shleifer and Vishny (1997) study provided that executives try to maximize their self-interest from the shareholder resources. Therefore a control mechanism is needed to mitigate this opportunistic behavior. Jensen and Meckling (1976) argue that the agency problem can be solved through management compensation and implementation of good governance. Corporate governance is the widest control to mitigate agency cost and improve firm's efficiency. In 1999 the OECD issued a document, The OECD Principles of Corporate Governance that emphasizes that corporations should be run best and foremost, in the interests of shareholders (OECD 1999). "Corporate governance involves a set of relationships between a company's management, its board, its shareholders and other stakeholders. Corporate governance also provides the structure through which the objectives of the company are set, and the means of attaining those objectives and monitoring performance are determined." (OECD Principles of Corporate 
Governance, 2nd Edition, 2004). Corporate governance covers the concepts, theories, and practices of boards and their directors and the relationship between boards and shareholders, top management, regulators and auditors and other stakeholders (Huq \& Bhuiyan, 2012). Some empirical investigations found that good corporate governance has a positive effect on firm's performance and market value (Sami, Wang, \& Zhou, 2011). Chowdhury (2004) showed a positive relationship between good corporate governance and market competitiveness and performance. Board performance of its monitoring duties usually is influenced by the effectiveness of the board, which in turn is influenced by factors such as board composition and quality, size of boards, the duality of CEO/Chairman positions, board diversity and ownership, information asymmetries and board culture (Brennan, 2006).

\section{OBJective OF THE Study}

The aim of this research is to examine the impact of corporate governance mechanisms on the performance of conventional banking companies listed in Dhaka Stock Exchange of Bangladesh. To achieve this aim, research objectives for the study are to examine the pattern of board structure in conventional banking companies of Bangladesh and to examine whether the different patterns of board structure and shareholdings have any influence on their performance. Therefore, the study extends and contributes to the body of research using data collected from annual report of selected banking companies listed in Dhaka Stock Exchange. The outcome will be further helpful to the decision makers of this industry as this sector was rarely explored earlier on this regard.

\section{Literature REVIEW}

In our country, Bangladesh Securities and Exchange Commission (BSEC), the regulatory authority, firstly, introduced corporate governance guideline in 2006 and later revised in 2012 to ensure proper monitoring and governance of the firms. All listed companies have to prepare the corporate governance compliance checklist since 2006. Before implementation of the guideline of corporate governance (amendment) 2012, only a few listed companies disclose the corporate governance information in details voluntarily.

Chhaochharia and Laeven (2009), also using the Institutional Shareholder Service (ISS) database, distinguish between governance attributes that are legally required and attributes that are adopted voluntarily. They show that firms that voluntarily adopt a more rigorous corporate governance structure are rewarded with a higher firm value. Aggarwal and Williamson (2006) and Brown and Caylor (2006) also use the ISS database to construct governance indices for U.S. firms only, and both find a positive relationship between corporate governance and firm value.Abbasi et al. (2102) using the food industry of companies listed on the Tehran Stock Exchange from 2002 to 2011, found strong and positive impact on corporate governance (focused on four aspects namely Ownership Concentration, Institutional Ownership, Chief Executive Officer duality and Board's Independence) on firm's value measured through Tobin's Q. Rouf (2012) examined the relationship between four corporate governance mechanisms (board size, independent director on board, chief executive officer duality and board audit committee) and value of the firm (performance) measures (return on assets, ROA and return on equity, ROE) based on a sample of 93 listed nonfinancial companies in Dhaka Stock Exchanges (DSE) 2006 and found a positive significant relationship between ROA and board independent director as well as chief executive however, but could not provide a significant relationship between the value of the firm measures (ROA and ROE) and board size and board audit committee. Dung To Thi (2011) investigated the relationship between corporate governance and firm value by using information taken from of Vietnamese Listed Companies on Ho Chi Minh Stock Exchange (HOSE) and Ha Noi Stock Exchange (HNX) at the yearend 2009. The empirical findings show that the dual position of CEO and Chairman has a positive relationship with firm value. Besides, the age of director and the number of directors meeting play important roles in firm value. However, no significant impact of board size, board gender diversity, top ten shareholders concentration and levels of state ownership on firm performance. Lastly, the regression model of market performance shows that the duality of CEO and Chairman and the number of independent directors are the significant impact on firm value. Khurram Khan et al., (2011) investigate the effect of corporate governance on firm's performance of the Tobacco Industry of Pakistan using data from 2004 to 2008 using multiple regression statistical technique to measure the relationships between dependent and independent variables. Ownership concentration, CEO duality \& Board's Independence are independent variables. The results show that there is a strong and positive impact of the corporate governance on firm's performance, Therefore, effective corporate governance mechanisms (including board composition and ownership structures) are important for creating value addition of the firm.

Swastika (2013), using data from the years 2005 annual reports of 51 food and beverage companies in Indonesia, showed that two of the corporate governance variables, the board of directors and audit quality, as well as firm size, are statistically significant in explaining earning management measured by discretionary accruals. Ozkan (2007) stated that corporate governance mechanisms such as board composition and ownership structures have the influence on compensation policy and reduce the agency conflicts between executives and shareholders.

Black (2001) studies a small sample of 21 firms in 1999, with very limited control variables, but reports a strong 
correlation between a corporate governance index and the market value of Russian firms.

Further study by Black et al. (2005), using time-series evidence from Russia for 1999-2004, found an economically important and statistically strong correlation between governance and market value in OLS with firm clusters and in firm random effects and firm fixed effects regressions.

\section{DeVELOPMENT OF HyPOTHESES}

Based on a literature review as well as some previous studies, the researchers indicated that proxy GCG mechanism through board size, independent board, female directors, institutional ownership, and audit committees as independent variables while the performance of the company as the dependent variable. To help understand the impact corporate governance mechanisms on firm's performance required a framework of thought. Of the basic theory outlined above, it can be described in a theoretical framework that is structured as follows:

\begin{tabular}{ll|}
\hline 1. & Board size, \\
2. & Independent board, \\
3. & Female directors, \\
4. Institutional ownership, &
\end{tabular} $\begin{gathered}\text { Firm } \\
\text { 5. }\end{gathered}$

Figure 1: Theoretical Framework

In family-controlled business in developing countries like Bangladesh, Board size is one of the major corporate governance mechanisms. It is determined on the basis of how much it influences the communication \& coordination and control management of a firm (Saha \& Akter, 2013). While large board size is considered fruitful for firms to secure its valuable resources and to reduce uncertainties (Goodstein, Gautum, \& Boeker, 1994; Pearce \& Zahra, 1992; Pfeffer, 1983; Uadiale, 2010) some other found potential problems within. But small board size is generally believed to improve the firm by maintaining proper coordination and communication and by reducing the possibility of free riding. Many empirical studies were found an insignificant relationship between board size and firm value (Rouf, 2012; Dung To Thi,2011; Mak and Kusandi, 2005; Sanda et al. 2005). I assume the hypothesis below:

$\mathrm{H}_{1}$ : The size of the board is positively related to the performance of the firm.

In Cadbury report (1992), there should be an effective composition of the board of directors to maintain their vitality. Beassley (1996) stated that the presence of independent directors on the board composition could reduce fraudulent financial reporting that increase the value of the company. In Sarbanes Oxley Act (2012) emphasizes the inclusion of independent directors. The proportion of independent directors is positively correlated with the value of the firm (Agrawal and Knoeber, 1996; Rouf, 2012;
Khurram Khan et al., 2011; Mukhtaruddin et al., 2014). But the relationship between independent directors and the firm value was negative (Klein,1998; Yermark,1996). I assume the hypothesis below:

$\mathrm{H}_{2}$ : Independent directors have positively related to the performance of the firm.

Earlier empirical research rarely focused on the presence of female directors on the board.

Robinson and Dechant (1997) stated that female directors are hard workers and have good communication skills with problem-solving and decision-making capacity in the entire board. Eagly and Carli (2003) find that females reach to directorship position and demonstrate that they are highly proficient, diligent, and sincere about responsibilities and take the best preparation before the board meeting and improve board effectiveness. Carter et al., (2003) finds a positive relation between percentage of female directors and firm performance. But Dung To Thi (2011) was found no significant impact of board gender diversity on firm performance. I assume the hypothesis below:

$\mathrm{H}_{3}$ : Female directors have positively related to the performance of the firm.

Institutional ownership has one of the important roles in reducing the agency problem that occurred. Institutional ownership acts as the controlling party and corporate managers. The greater the level of stock ownership by institutions, then the control mechanisms on performance management will be more effective. The level of institutional ownership in a substantial proportion will affect the market value of the firm (Shleifer and Vishny, 1986; Widanar, 2009).

Previous studies were found the positive relation between institutional ownership and firm value (McConnell and Servaes, 1990; Abbasi et al. 2102; Mukhtaruddin et al., 2014). But Loderer and Martin (1997) find no significant relationship between institutional ownership and firm performance. I assume the hypothesis below:

$\mathrm{H}_{4}$ : Institutional ownership has positively related to the performance of the firm.

The role of the audit committee is essential in implementing corporate governance principles and improving the value of the firm. In case of any financial manipulation, the audit committee is held accountable for their actions as the availability of transparent financial information reduces the information asymmetry and improves the value of the firm (Bhagat and Jefferis, 2002). Mukhtaruddin et al., 2014 found that audit committee has a positive and insignificant influence towards firm value. But Rouf (2012) could not provide a significant relationship between the values of the firm measures and board audit committee. I assume the hypothesis below:

$\mathrm{H}_{5}$ : Audit committee has positively related to the performance of the firm. 


\section{RESEARCH METHOD}

\section{Sample Selection}

After the independence, the banking industry in Bangladesh started its journey with six nationalized commercialized banks, two state-owned specialized banks and three foreign banks. In the 1980's banking industry achieved a significant expansion with the entrance of private banks. At present, there are fifty six scheduled banks in Bangladesh which operate under full control and supervision of Bangladesh Bank. The financial sector of Bangladesh is dominated by banks and the share of this sector in the Gross Domestic Product (GDP) is 2.87\% for the fiscal year 2014-15 (Bangladesh Economic Review 2015). Furthermore, during the last ten years, the total asset of the banking sector has grown rapidly which is the sign of the remarkable contribution of the banking sector in the development of the country (Ali et al., 2016).

The population of my study is twenty-three listed conventional banks in Dhaka Stock Exchange.

Therefore, fourteen banks are selecting as a sample of my study. Name of banks are shown in Table 1.

Table 1: Sample Bank listed in Dhaka Stock Exchange

\begin{tabular}{|l|}
\hline 1. AB Bank Ltd. \\
\hline 2. Bank Asia Ltd. \\
\hline 3. BRAC Bank Ltd. \\
\hline 4. The City Bank Ltd. \\
\hline 5. Dutch-Bangla Bank Ltd. \\
\hline 6. Eastern Bank Ltd. \\
\hline 7. IFIC Bank Ltd. \\
\hline 8. Mercantile Bank Ltd. \\
\hline 9. National Credit and Commerce Bank Ltd. \\
\hline 10. Prime Bank Ltd. \\
\hline 11. Pubali Bank Ltd. \\
\hline 12. Trust Bank Ltd. \\
\hline 13. United Commercial Bank Ltd. \\
\hline 14. Uttara Bank Limited \\
\hline
\end{tabular}

\section{Data Collection Method}

Secondary data from the annual reports of the sample banks for the years 2007 to 2016 used to complete this work. The end-of-year number of shares outstanding and end-of-year share price from Dhaka Stock Exchange (DSE) and annual reports have been used to calculate the market value of equity.

\section{Measurement of Variables}

Firm's performance is dependent variable measured by Return on Assets (ROA) (an accounting based performance measure)-calculated as "Profit after tax" (PAT) scaled by the average of total assets and another one is Tobin's Q-the ratio of the market value of the firm to total shareholders' equity of the firm (a market-based performance measure). Tobin's $\mathrm{Q}$ is sometimes written as
"Tobin's-q", "Tobin's Q" or simply Q. It is also called Tobin's Quotient since the $Q$ stands for Quotient. Sometimes, people call it the "Brainard-Tobin $\mathrm{Q}^{\prime}$. The market value of the firm is calculated by multiplying market value per share to a total number of shares outstanding. Board size, Independent board, Female directors, Institutional ownership, and Audit committees are proxies of Corporate Governance Mechanisms and also considered as independent variables.

Table 2: Independent variables and their measurement in this study

\begin{tabular}{|l|l|}
\hline Board size & $\begin{array}{l}\text { The number of board members } \\
\text { (Suranta and Machfoedz, 2003). }\end{array}$ \\
\hline $\begin{array}{l}\text { Independent } \\
\text { board }\end{array}$ & $\begin{array}{l}\text { The proportion of independent } \\
\text { director on the board. }\end{array}$ \\
\hline Female director & $\begin{array}{l}\text { The proportion of female director on } \\
\text { the board. (Rahaman,2016) }\end{array}$ \\
\hline $\begin{array}{l}\text { Institutional } \\
\text { ownership }\end{array}$ & $\begin{array}{l}\text { The proportion of shares held by the } \\
\text { institution (s). }\end{array}$ \\
\hline Audit Committee & $\begin{array}{l}\text { The number of members in audit } \\
\text { committee. (Mukhtaruddin et al.2014) }\end{array}$ \\
\hline
\end{tabular}

\section{Model Specification}

In order to examine the relationship between corporate governance mechanisms and firm performance, the following model is developed:

$Y i, t=\alpha+\beta 1$ BODSZ $i, t+\beta 2 I D i, t+\beta 3 F D i, t+\beta 4 I O i, t$ $+\beta 5 A C i, t+\varepsilon$

Where,

$\mathrm{Y} i$, is alternatively ROA $i$, and Tobin's Q $i$,

BODSZ $i$, is the size of the board for $i$ th firm at time $t$,

ID $i$, is the proportion of independent director on the board for $i$ th firm at time $t$,

$F D i$, is the proportion of female director on the board for $i$ th firm at time $t$,

$I O i$, is the proportion of shares held by the institution (s) for $i$ th firm at time $t$,

$A C i$, is the number of members in audit committee for $i$ th firm at time $t$,

$\alpha$ is the intercept, $\beta i$ is the regression coefficient and $\varepsilon$ is the error term,

The subscript $i$ represents the different firms and $t$ represents the different years.

\section{Empirical Result Analysis}

Table 3: Descriptive statistics

\begin{tabular}{|l|c|c|c|c|}
\hline & Minimum & Maximum & Mean & Std. Deviation \\
\hline TOBQ & 0.2292 & 13.3857 & 2.0472 & 1.8316 \\
\hline BODSZ & 5 & 27 & 13.35 & 4.3740 \\
\hline
\end{tabular}




\begin{tabular}{|l|c|c|c|c|}
\hline ID & 0.0000 & 0.6000 & 0.1278 & 0.1212 \\
\hline FD & 0.0000 & 0.5000 & 0.1259 & 0.1127 \\
\hline IO & 0.0000 & 0.6482 & 0.2002 & 0.1466 \\
\hline AC & 0 & 5 & 3.81 & 0.9440 \\
\hline ROA & 0.0019 & 0.0352 & 0.0140 & 0.0065 \\
\hline
\end{tabular}

To test the propositions made in this study, this section is devoted to present the result of the analysis conducted on collected data. Data has been analyzed using the Statistical Package for Social Sciences; (SPSS Version 15.0).The descriptive statistics of all the variables used in the study are shown in table 3 . As shown in the table, average firm performance is $204.72 \%$ ranging from $22.92 \%$ to $1338.57 \%$ under Tobin's Q performance measure and $1.40 \%$ ranging from $0.19 \%$ to $3.52 \%$ under the ROA performance measure. It indicates that for every BDT 100 invested as an asset there is a return of BDT 1.40. The average board size is found to be 13 directors ranging from 5 to 27 . The result indicates that $12.78 \%$ directors acting as independent sitting on the board ranging from $0 \%$ to $60 \%$ for selected firms of the study. On the other hand, there are $12.59 \%$ female directors sitting on the board ranging from $0 \%$ to $50 \%$. Shareholding position by institutions is presented $20.02 \%$ ranging from $0 \%$ to $64.82 \%$. The average member of the audit committee is 4 ranging from 0 to 5 .

Table 4: Correlation coefficient among variables

\begin{tabular}{|c|c|c|c|c|c|c|c|}
\hline & & тове & BoDsz & ID & FD & 10 & $A C$ \\
\hline \multirow{2}{*}{ TOHO } & Fourton Correlation & 1 & & & & & \\
\hline & Sig, (2)tailed & & & & & & \\
\hline \multirow{2}{*}{ HoDsz } & Fearsen Correlation & $-0,044$ & 1 & & & & \\
\hline & Sig, (2-tailed) & $0 ., 1 \times 8$ & & & & & \\
\hline \multirow{2}{*}{ m } & Pearson Correlation & $-0.296\left({ }^{* 11}\right)$ & $\left.-0.432 f^{-2}\right)$ & 1 & & & \\
\hline & Sig. [2-tailed) & 0.000 & 0.000 & & & & \\
\hline \multirow{2}{*}{ HD } & Pearson Correlation & $\left.-0.205 \gamma^{*}\right\rangle$ & $-0,070$ & $\left.0.23 x^{-1}\right)$ & 1 & & \\
\hline & Sip, [2-tailed & 0.915 & 0.373 & Q905 & & & \\
\hline \multirow{2}{*}{10} & Fearson Correlation & $-0.300[-1 / 3$ & $\left.-0172 x^{*}\right)$ & 0.358 (") & $\left.012655^{24}\right)$ & 1 & \\
\hline & Sig [2-tailed & 0000 & .042 & 0000 & 0.002 & & \\
\hline \multirow{2}{*}{$\mathrm{AC}$} & Pearson Correlation & $-1.315 \mathrm{c}^{\mathrm{m})}$ & $26+\left({ }^{n+1}\right)$ & 0.143 & -0.144 & 0.083 & 1 \\
\hline & Sige (2-4ailed) & 0.000 & 0.902 & 0092 & 0.090 & 0.325 & \\
\hline \multirow{2}{*}{ ROA } & Poasson Correlation & $\left.0.390^{* *}\right)$ & $0.183 \%$ & $-0.375 \times 47$ & -0.009 & -0046 & $\left.-0.2877^{-4}\right)$ \\
\hline & Sig, (2-tailed) & 0,000 & 0.031 & 0,000 & 0.351 & 0.586 & 0.001 \\
\hline
\end{tabular}

${ }^{* *}$ Correlation is significant at the 0.01 level (2-tailed).

*Correlation is significant at the 0.05 level (2-tailed).

To measure the strength of association among the variables, Pearson correlation analysis is conducted on the variables. The results are shown in Table 4. Tobin's $Q$ is negatively correlated to board size, the proportion of independent directors, the proportion of female directors, institutional ownership and the number of member in audit committee. The negative correlation of Tobin's Q with the proportion of independent directors, institutional ownership and the number of member in audit committee is significant at the level of 0.01 . Similarly the negative correlation of Tobin's $Q$ with the proportion of female directors is significant at the level of 0.05 and with board size is not significant. On the other hand, beside a negative correlation with Tobin's Q, ROA is positively correlated with board size and significant at the level of 0.05 . Moreover ROA is negatively correlated to the proportion of independent directors, the proportion of female directors, institutional ownership and the number of member in audit committee. The negative correlation of ROA with the proportion of independent directors and the number of member in audit committee is significant at the level of 0.01 . But the negative relationship of ROA with the proportion of female directors and institutional ownership is insignificant.

Table 5. Regression Analysis (Tobin's Q as dependent variable)

\begin{tabular}{|l|l|l|l|l|}
\hline \multicolumn{5}{|l|}{ Model Summary } \\
\hline Model & R & $\begin{array}{l}\text { R } \\
\text { Square }\end{array}$ & $\begin{array}{l}\text { Adjusted } \\
\text { R Square }\end{array}$ & $\begin{array}{l}\text { Std. Error of } \\
\text { the Estimate }\end{array}$ \\
\hline 1 & $.454(a)$ & 235 & 206 & 1.6319670 \\
\hline
\end{tabular}

\begin{tabular}{|l|l|l|l|l|l|l|}
\hline \multicolumn{2}{|l|}{ ANOVA(b) } \\
\hline \multirow{2}{*}{ Model } & $\begin{array}{l}\text { Sum of } \\
\text { Squares }\end{array}$ & df & $\begin{array}{l}\text { Mean } \\
\text { Square }\end{array}$ & F & Sig. \\
\hline \multirow{3}{*}{1} & Regression & 109.438 & 5 & 21.888 & 8.218 & $.000(\mathrm{a})$ \\
\cline { 2 - 8 } & Residual & 356.884 & 134 & 2.663 & & \\
\cline { 2 - 7 } & Total & 466.322 & 139 & & & \\
\hline a Predictors: (Constant), AC, IO, FD, BODSZ, ID \\
\hline \multicolumn{6}{|l|}{ b Dependent Variable: TOBQ } \\
\hline
\end{tabular}

\begin{tabular}{|l|l|l|l|l|}
\hline \multicolumn{5}{|l|}{ Model Summary } \\
\hline Model & R & $\begin{array}{l}\text { R } \\
\text { Square }\end{array}$ & $\begin{array}{l}\text { Adjusted } \\
\text { R Square }\end{array}$ & $\begin{array}{l}\text { Std. Error of } \\
\text { the Estimate }\end{array}$ \\
\hline 1 & $.484(\mathrm{a})$ & .235 & .206 & 1.6319670 \\
\hline \multicolumn{5}{|c|}{ a Predictors: (Constant), AC, IO, FD, BODSZ, ID } \\
\hline
\end{tabular}

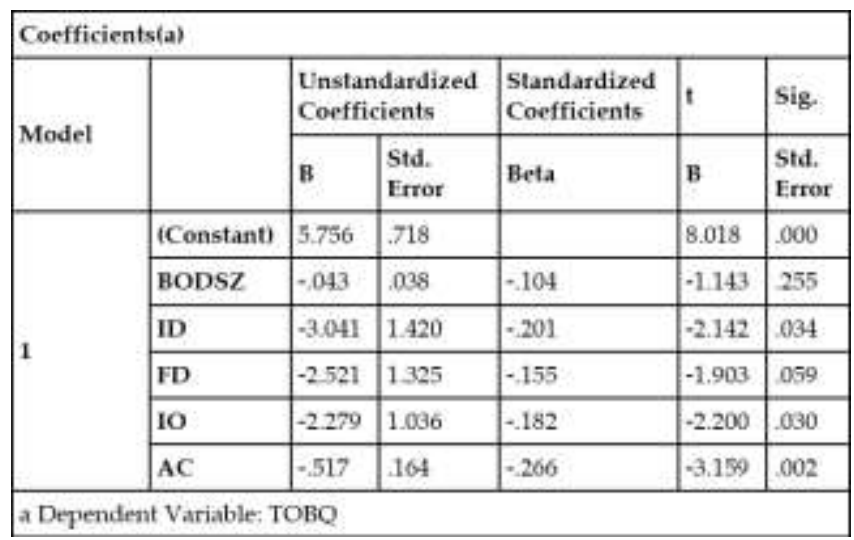


Table 6: Regression Analysis (ROA as dependent variable)

\begin{tabular}{|l|l|l|l|l|}
\hline \multicolumn{5}{|l|}{ Model Summary } \\
\hline Model & R & R Square & $\begin{array}{l}\text { Adjusted } \\
\text { R Square }\end{array}$ & $\begin{array}{l}\text { Std. Error of } \\
\text { the Estimate }\end{array}$ \\
\hline II & $.476(\mathrm{a})$ & .226 & .197 & .0058698 \\
\hline \multicolumn{5}{|l|}{ Predictors: (Constant), AC, IO, FD, BODSZ, ID } \\
\hline
\end{tabular}

\begin{tabular}{|l|l|l|l|l|l|l|}
\hline \multicolumn{2}{|l|}{ ANOVA(b) } \\
\hline \multirow{2}{*}{ Model } & $\begin{array}{l}\text { Sum of } \\
\text { Squares }\end{array}$ & df & $\begin{array}{l}\text { Mean } \\
\text { Square }\end{array}$ & F & Sig. \\
\hline \multirow{3}{*}{1} & Regression & .001 & 5 & .000 & 7.839 & $.000(\mathrm{a})$ \\
\cline { 2 - 8 } & Residual & .005 & 134 & .000 & & \\
\cline { 2 - 7 } & Total & .006 & 139 & & & \\
\hline \multirow{2}{*}{ a Predictors: (Constant), AC, IO, FD, BODSZ, ID } \\
\hline b Dependent Variable: ROA
\end{tabular}

\begin{tabular}{|c|c|c|c|c|c|c|}
\hline \multicolumn{7}{|c|}{ Coefficients(a) } \\
\hline \multirow[t]{2}{*}{ Model } & & \multicolumn{2}{|c|}{$\begin{array}{l}\text { Unstandardized } \\
\text { Coefficients }\end{array}$} & \multirow{2}{*}{$\begin{array}{c}\begin{array}{c}\text { Standardized } \\
\text { Coefficients }\end{array} \\
\text { Beta }\end{array}$} & \multirow{2}{*}{ t } & \multirow{2}{*}{$\frac{\text { Sig. }}{\text { Std. Error }}$} \\
\hline & & B & Std. Error & & & \\
\hline \multirow{6}{*}{11} & (Constant) & 021 & .003 & & 7.952 & .000 \\
\hline & BODSZ & .000 & 000 & .154 & 1.684 & .094 \\
\hline & ID & -.016 & .005 & -.293 & $-3,104$ & .002 \\
\hline & FD & -004 & .005 & -.077 & -.941 & 348 \\
\hline & 10 & .006 & .004 & .131 & 1.570 & .119 \\
\hline & $A C$ & -.002 & .001 & -307 & -3.628 & .000 \\
\hline
\end{tabular}

Table 5 and Table 6 show the results of the coefficient estimates with both Tobin's $\mathrm{Q}$ and ROA as the dependent variable. Besides, the table also shows the model summary of regression analysis with adjusted $\mathrm{R}$ square measure and $F$ statistics value. The adjusted $R$ square value, indicating the explanatory power of the independent variables, is 0.206 and 0.197 respectively for Tobin's Q and ROA. It indicates that $20.60 \%$ of the variation in Tobin's $Q$ and $19.70 \%$ of the variation in ROA is explained by the variation in the independent variables.

From the result of the analysis, the analysis of variance (ANOVA) generates a significant 0.000 for Tobin's $Q$ and ROA and indicating model is significant at the level of 0.01 . This shows that the explanatory variables are linearly related to both measures of firm's performance and the model seems to have some validity.

From Table 5, Tobin's $Q$ as dependent variable is negatively associated with other independent variables (e.g. board size, the proportion of independent directors on board, the proportion of female directors in board, institutional ownership and the number of member of audit committee) but significant with the proportion of independent directors on board and Institution ownership at the level of 0.05 as well as with size of audit committee at level of 0.01 and insignificant with the proportion of female directors on board as well as board size.
On the other hand ROA as dependent variable is negatively associated with the proportion of independent directors on board, the proportion of female directors on board and the number of member in audit committee but significant with the proportion of independent directors on board as well as size of audit committee at level of 0.01 and insignificant with the proportion of female directors on board. But ROA as the dependent variable is positively associated with institutional ownership but insignificant. Board size as the independent variable is not related to ROA as the dependent variable.

\section{CONCLUSION}

The aim of this study is to empirically examine the impact of corporate governance mechanisms on firm's performance on listed conventional banking companies at Dhaka Stock Exchange. Based on previous empirical studies of this nature, a number of variables have been identified that to explain the impact of corporate governance mechanisms on firm's performance. Collected data on these variables including Tobin's Q, ROA, Board size, and the proportion of independent directors on board, the proportion of female directors on the board, institutional ownership and the size of the audit committee are thus analyzed to test the hypothesis proposed in the study. Results generated from the data analysis show that the performance of the firm is negatively correlated with independent directors on board as well as the size of the audit committee and significant at the level of 0.01 . The proportion of independent directors on board and size of the audit committee as independent variables is significant negative with the performance of the firm. The negative relation between Tobin's $Q$ and Independent directors in the board is significant at the level 0.05 . The negative association between Tobin's $Q$ and size of the audit committee is significant at the level 0.01 . The negative relationship of ROA with independent directors on the board as well as the size of the audit committee is significant at level 0.01.Independent directors may not able to increase the performance of listed banking companies in Dhaka Stock Exchange as the role of independent directors is hardly independent. The effective performance of independent directors is contingent on varies issues mainly expertise, independent from internal management and financial transaction with the organization. Moreover, the proportion of independent directors on the board is small enough to play their strong monitoring role on the board. Audit committee should be given a level playing field in making decisions for effective and efficient operations of the company and included majority portion of independent directors. Institutional ownership and the proportion of female directors on the board are negatively correlated with the performance of the firm. But this relationship is significant only market-based performance measure (Tobin's Q). In Bangladesh, Investment Corporation of Bangladesh (ICB) is the main institutional shareholder and they could not nominate in each company because of the shortage of manpower and right expertise. Furthermore, this study may be improved by including more companies and some other variables that may affect corporate financial performance. This study could be further extended to other industry. 


\section{REFERENCES}

Abbasi M., Kalantari E. \& Abbasi H. (2102), "Impact of Corporate Governance Mechanisms on Firm Value Evidence from the Food Industry of Iran". Journal of Basic and Applied Scientific Research, V-2 (5) pp. 4712-4721.

Aggarwal R. \& Williamson R. (2006), "Did new regulations target the relevant corporate governance attributes?". Working Paper, Georgetown University. February 12.

Agrawal, A. \& Knoeber, C.R (1996),"Firm performance and mechanisms to control agency problems between managers and shareholders". Journal of Financial and Quantitative Analysis, V-31(3) pp. 377-397.

Beasley, M. (1996), "An empirical analysis between the board of director composition and financial statement fraud". The Accounting Review, V-71 (4), pp. 443-466.

Berle A.\& Means G. (1934), The Modern Corporation And Private Property, Transaction Publishers, New Brunswick, U.S.A.

Bhagat S. \& Jefferis R. (2002), The Econometrics of Corporate Governance Studies. MIT Press, Cambridge.

Black B.S., Love I. \& Rachinsky A. (2005), Corporate Governance Indices and Firms' Market Values: Time Series Evidence from Russia, European Corporate Governance Institute, University of Texas School of Law, November.

Black, B. (2001) "Does corporate governance matter? A crude test using Russian data" University of Pennsylvania Law Review, V-149(2), pp. 2131-2150.

Brainard, William C.; James, Tobin. (1968). "Pitfalls in Financial Model Building." American Economic Review. V-58(2) pp.99-122.

Brennan N. (2006), "Boards of Directors and Firm Performance: Is there an expectations gap?" Corporate Governance: An International Review, V-14(6) pp. 577-593

Brown L. D. \& Claylor M. L. (2004), "Corporate Governance and Firm Performance." Working Paper, Georgia State University, USA. December 7.

Cadbury, S. A. (1992), “Committee on the Financial Aspects of Corporate Governance" United Kingdom, London Stock Exchange.

Chhaochharia V. \& Laeven L. (2009), "Corporate governance norms and practices". Journal of Financial Intermediation V18(3), pp.405-431.

Chowdhury D. K (2004), "Corporate Governance". Incentives, Control and Development: Governance in Private and Public Sector with Special Reference to Bangladesh, Dhaka University Publishing Society, Dhaka, Bangladesh, pp. 109-158.

Goodstein J., Gautum K., \& Boeker, W. (1994) "The effect of Board size and Diversity on Strategic Change". Strategic Management Journal, V-15(3), pp. 241-250.

Huq B. I. \& Bhuiyan M. Z. (2012), "Corporate Governance-It's Problems \& Prospects in Banking Industry in Bangladesh". World Review of Business Research, V-2 (2), pp.16-31.

Jensen M. C. \& Meckling H. (1976), “Theory of the Firm: Managerial Behavior, Agency Costs and Ownership Structure". Journal of Financial Economics, V. 3, (4), pp.305-360.

Khan K., Nemati A.R. \& Ifthikar M. (2011) "Impact of Corporate Governance on Firm's value of Tobacco Industry of Pakistan". International Research Journal of Finance and Economics, Issue 61.
Loderer C. \& Martin K. (1997), “Executive stock ownership and performance tracking faint traces". Journal of Financial Economics, V-45(2), pp. 223-255.

Mak, Y. T., \& Kusnadi, Y. (2005), "Size really matters: Further evidence on the negative relationship between board size and firm value". Pacific-Basin Finance Journal, V-13, pp. 301-318.

Mukhtaruddin, Abukosim, Nurcahaya C. \& Ferina I. (2014) "Ownership Structure and Firm Values: Empirical Study on Indonesia Manufacturing Listed Companies". Journal of Arts, Science \& Commerce, V-5(4), pp. 1-14.

Organization for Economic Co-operation and Development (OECD), 1999, “OECD Principles of Corporate Governance".

Ozkan, N. (2007) "Do corporate governance mechanisms influence CEO compensation? An empirical investigation of Uk companies". Journal of Multinational Financial Management, V-17, pp. 349-364.

Pearce H. \& Zahra S. A. (1992), "Board Composition from a Strategic Contingency Perspective". Journal of Management Studies, V-29, pp.411-438.

Pfeffer, J. (1983), “Organizational demography" In L. L. Cummings \& B. M. Staw (Eds.), Research in organizational behavior, Vol. 5, pp. 299-357. Greenwich, CT: JAI Press.

Rahman M. M (2016), "Determinants of CEO Compensation: Empirical Evidence from Listed Banks of Bangladesh". Dhaka University Journal of Business Studies, V-1(1), pp. (127-161).

Rouf A. (2012), “The Relationship between Corporate Governance and Value of the Firm in Developing Countries: Evidence from Bangladesh". Journal of Economics and Business Research, V- XVIII, No. 1, pp. 73-85.

Saha, A. K., \& Akter, S. (2013), "Corporate governance and voluntary disclosure practices of financial and nonfinancial sector companies in Bangladesh". Journal of Applied Management Accounting Research, V-11(2), pp. 45-62.

Sami H., Wang J. \& Zhou H. (2011), "Corporate governance and operating performance of Chinese listed firms". Journal of International Accounting, Auditing and Taxation V-20(2), pp. 106-114.

Sanda, A., Mikailu, A. S., Garba, T (2005), “Corporate governance mechanisms and firm financial performance in Nigeria. AERC Research Paper 149, Nairobi.

Shleifer, A. \& R. Vishny (1997), “A survey of corporate governance". Journal of Finance, V-52(2), pp. 737-783.

Suranta and Machfoedz (2003), Analysis of the structure of ownership, value enterprise, investment and the size of the board of directors. National Conference on Accounting. Surabaya.

Swastika D.L (2013), “Corporate Governance, Firm Size, and Earning Management: Evidence in Indonesia Stock Exchange". Journal of Business and Management, V-10(4) pp. 77-82.

Thi D.T. (2011), “CORPORATE GOVERNANCE - Empirical Research on Board Size, Board Composition, Board Activity, Ownership Concentration and Their Effects on Performance of Vietnamese Listed Companies". Master Thesis in Business Administration University of Boras, 2-49.

Uadiale, O. M. (2010), "The Impact of Board Structure on Corporate Financial Performance in Nigeria". International Journal of Business and Management, V-5(10), pp. 155-166.

$$
--0-
$$




\section{APPENDIX}

All variables and their measurement of all selected Banks

\begin{tabular}{|c|c|c|c|c|c|c|c|c|}
\hline \multirow{11}{*}{$\begin{array}{c}\text { AB } \\
\text { Bank } \\
\text { Ltd }\end{array}$} & Year & $\begin{array}{c}\text { Tobin's Q } \\
\text { Ratio }\end{array}$ & $\begin{array}{c}\text { Board } \\
\text { Size }\end{array}$ & $\begin{array}{c}\text { Independent } \\
\text { board }\end{array}$ & $\begin{array}{l}\text { Female } \\
\text { director }\end{array}$ & $\begin{array}{c}\text { Institutional } \\
\text { ownership }\end{array}$ & $\begin{array}{c}\text { Audit } \\
\text { Committee }\end{array}$ & $\begin{array}{c}\text { Return } \\
\text { on Assets }\end{array}$ \\
\hline & 2016 & 0.6501 & 11 & 0.1818 & 0.0000 & 0.3140 & 5 & 0.0044 \\
\hline & 2015 & 0.5493 & 13 & 0.1538 & 0.0000 & 0.5889 & 5 & 0.0048 \\
\hline & 2014 & 0.8768 & 12 & 0.1667 & 0.0000 & 0.5505 & 5 & 0.0054 \\
\hline & 2013 & 0.7696 & 14 & 0.2143 & 0.0714 & 0.5550 & 5 & 0.0053 \\
\hline & 2012 & 0.9297 & 14 & 0.0714 & 0.0714 & 0.5673 & 5 & 0.0088 \\
\hline & 2011 & 1.6951 & 14 & 0.0714 & 0.0714 & 0.6482 & 5 & 0.0093 \\
\hline & 2010 & 3.6534 & 14 & 0.0714 & 0.0714 & 0.4867 & 3 & 0.0308 \\
\hline & 2009 & 2.9910 & 14 & 0.0714 & 0.0714 & 0.4937 & 3 & 0.0352 \\
\hline & 2008 & 2.7275 & 14 & 0.0714 & 0.0714 & 0.4171 & 3 & 0.0312 \\
\hline & 2007 & 1.4064 & 11 & 0.0000 & 0.0000 & 0.4171 & 3 & 0.0341 \\
\hline \multirow{10}{*}{$\begin{array}{l}\text { Bank } \\
\text { Asia } \\
\text { Ltd. }\end{array}$} & 2016 & 0.8286 & 13 & 0.3077 & 0.2308 & 0.3634 & 5 & 0.0065 \\
\hline & 2015 & 0.7297 & 16 & 0.3750 & 0.2500 & 0.3490 & 5 & 0.0126 \\
\hline & 2014 & 0.7556 & 16 & 0.2500 & 0.3125 & 0.3390 & 4 & 0.0128 \\
\hline & 2013 & 1.0914 & 15 & 0.2000 & 0.3333 & 0.2921 & 3 & 0.0096 \\
\hline & 2012 & 1.0393 & 14 & 0.2143 & 0.2857 & 0.2500 & 3 & 0.0070 \\
\hline & 2011 & 1.5924 & 15 & 0.0667 & 0.0667 & 0.2306 & 3 & 0.0172 \\
\hline & 2010 & 3.6471 & 15 & 0.0667 & 0.0667 & 0.2050 & 3 & 0.0222 \\
\hline & 2009 & 1.8478 & 13 & 0.0769 & 0.0769 & 0.2678 & 3 & 0.0218 \\
\hline & 2008 & 2.0054 & 13 & 0.0769 & 0.1538 & 0.1812 & 4 & 0.0187 \\
\hline & 2007 & 2.8242 & 11 & 0.0000 & 0.1818 & 0.1817 & 3 & 0.0211 \\
\hline \multirow{10}{*}{$\begin{array}{c}\text { BRAC } \\
\text { Bank } \\
\text { Ltd. }\end{array}$} & 2016 & 2.1239 & 7 & 0.4286 & 0.2857 & 0.5307 & 3 & 0.0189 \\
\hline & 2015 & 1.8359 & 7 & 0.5714 & 0.4286 & 0.4700 & 3 & 0.0113 \\
\hline & 2014 & 1.4860 & 7 & 0.4286 & 0.4286 & 0.4400 & 4 & 0.0109 \\
\hline & 2013 & 1.2472 & 5 & 0.6000 & 0.4000 & 0.4530 & 4 & 0.0078 \\
\hline & 2012 & 1.3211 & 6 & 0.5000 & 0.5000 & 0.4410 & 3 & 0.0035 \\
\hline & 2011 & 1.5288 & 6 & 0.3333 & 0.3333 & 0.4488 & 3 & 0.0136 \\
\hline & 2010 & 2.4340 & 6 & 0.3333 & 0.3333 & 0.4635 & 3 & 0.0155 \\
\hline & 2009 & 1.7369 & 7 & 0.1429 & 0.2857 & 0.4550 & 3 & 0.0156 \\
\hline & 2008 & 2.4120 & 8 & 0.1250 & 0.2500 & 0.4550 & 3 & 0.0164 \\
\hline & 2007 & 0.6328 & 8 & 0.1250 & 0.1250 & 0.4711 & 3 & 0.0162 \\
\hline \multirow{10}{*}{$\begin{array}{l}\text { The } \\
\text { City } \\
\text { Bank } \\
\text { Ltd. }\end{array}$} & 2016 & 0.9415 & 14 & 0.1429 & 0.2143 & 0.1800 & 4 & 0.0170 \\
\hline & 2015 & 0.7004 & 13 & 0.0769 & 0.1538 & 0.2361 & 4 & 0.0180 \\
\hline & 2014 & 0.8150 & 16 & 0.0625 & 0.2500 & 0.2190 & 5 & 0.0140 \\
\hline & 2013 & 0.7717 & 15 & 0.0000 & 0.2857 & 0.0989 & 5 & 0.0070 \\
\hline & 2012 & 0.9428 & 14 & 0.0000 & 0.2857 & 0.1509 & 5 & 0.0060 \\
\hline & 2011 & 1.4842 & 14 & 0.0000 & 0.2857 & 0.0915 & 5 & 0.0200 \\
\hline & 2010 & 3.3696 & 12 & 0.0000 & 0.2500 & 0.1800 & 3 & 0.0220 \\
\hline & 2009 & 1.9558 & 12 & 0.0000 & 0.2500 & 0.2615 & 3 & 0.0120 \\
\hline & 2008 & 1.4626 & 12 & 0.0000 & 0.2500 & 0.1197 & 3 & 0.0080 \\
\hline & 2007 & 2.9975 & 11 & 0.0000 & 0.2727 & 0.1376 & 0 & 0.0070 \\
\hline \multirow{10}{*}{$\begin{array}{l}\text { Ducth } \\
\text { Bangla } \\
\text { Bank } \\
\text { Ltd. }\end{array}$} & 2016 & 1.3268 & 7 & 0.2857 & 0.0000 & 0.0700 & 3 & 0.0070 \\
\hline & 2015 & 1.2850 & 7 & 0.2857 & 0.0000 & 0.0640 & 3 & 0.0130 \\
\hline & 2014 & 1.4607 & 7 & 0.2857 & 0.1429 & 0.0280 & 3 & 0.0110 \\
\hline & 2013 & 1.6582 & 9 & 0.2222 & 0.1111 & 0.0410 & 3 & 0.0120 \\
\hline & 2012 & 2.1059 & 9 & 0.2222 & 0.1111 & 0.0510 & 4 & 0.0170 \\
\hline & 2011 & 3.6488 & 7 & 0.1429 & 0.1429 & 0.0430 & 3 & 0.0190 \\
\hline & 2010 & 6.5477 & 8 & 0.1250 & 0.1250 & 0.0300 & 3 & 0.0220 \\
\hline & 2009 & 6.7489 & 9 & 0.1111 & 0.0000 & 0.0136 & 4 & 0.0160 \\
\hline & 2008 & 13.385 & 10 & 0.1000 & 0.0000 & 0.0138 & 5 & 0.0150 \\
\hline & 2007 & 5.8582 & 6 & 0.0000 & 0.0000 & 0.0140 & 3 & 0.0101 \\
\hline
\end{tabular}




\begin{tabular}{|c|c|c|c|c|c|c|c|c|}
\hline \multirow{10}{*}{$\begin{array}{c}\text { Eastern } \\
\text { Bank } \\
\text { Ltd. }\end{array}$} & 2016 & 0.9908 & 11 & 0.1818 & 0.0909 & 0.1041 & 5 & 0.0133 \\
\hline & 2015 & 0.8528 & 11 & 0.1818 & 0.0909 & 0.1088 & 5 & 0.0123 \\
\hline & 2014 & 0.8276 & 11 & 0.1818 & 0.0909 & 0.1149 & 4 & 0.0128 \\
\hline & 2013 & 0.9639 & 11 & 0.1818 & 0.0909 & 0.1149 & 5 & 0.0168 \\
\hline & 2012 & 1.1324 & 11 & 0.1818 & 0.0909 & 0.1246 & 5 & 0.0172 \\
\hline & 2011 & 2.0677 & 11 & 0.0909 & 0.0000 & 0.0982 & 5 & 0.0252 \\
\hline & 2010 & 3.1278 & 10 & 0.1000 & 0.1000 & 0.0977 & 3 & 0.0319 \\
\hline & 2009 & 1.9071 & 10 & 0.1000 & 0.1000 & 0.1074 & 3 & 0.0234 \\
\hline & 2008 & 1.7267 & 10 & 0.1000 & 0.1000 & 0.1083 & 3 & 0.0168 \\
\hline & 2007 & 2.8954 & 11 & 0.0000 & 0.1818 & 0.1083 & 3 & 0.0110 \\
\hline \multirow{10}{*}{$\begin{array}{c}\text { IFIC } \\
\text { Bank } \\
\text { Ltd. }\end{array}$} & 2016 & 0.8194 & 8 & 0.2500 & 0.1250 & 0.2434 & 3 & 0.0065 \\
\hline & 2015 & 0.9157 & 8 & 0.2500 & 0.1250 & 0.2144 & 3 & 0.0053 \\
\hline & 2014 & 0.9603 & 10 & 0.3000 & 0.0000 & 0.1947 & 4 & 0.0107 \\
\hline & 2013 & 1.3256 & 9 & 0.3333 & 0.0000 & 0.1819 & 4 & 0.0109 \\
\hline & 2012 & 1.8241 & 9 & 0.3333 & 0.0000 & 0.3391 & 5 & 0.0107 \\
\hline & 2011 & 2.8346 & 12 & 0.0833 & 0.0000 & 0.3366 & 4 & 0.0093 \\
\hline & 2010 & 5.3718 & 14 & 0.0714 & 0.0000 & 0.0000 & 3 & 0.0249 \\
\hline & 2009 & 3.8234 & 12 & 0.0833 & 0.0000 & 0.0000 & 3 & 0.0143 \\
\hline & 2008 & 4.9831 & 14 & 0.0714 & 0.0000 & 0.0000 & 4 & 0.0144 \\
\hline & 2007 & 5.9559 & 14 & 0.0000 & 0.0000 & 0.0000 & 4 & 0.0242 \\
\hline \multirow{10}{*}{$\begin{array}{c}\text { Mercan } \\
\text { tile } \\
\text { Bank } \\
\text { Ltd. }\end{array}$} & 2016 & 0.6640 & 14 & 0.1429 & 0.0000 & 0.0780 & 5 & 0.0115 \\
\hline & 2015 & 0.5098 & 14 & 0.1429 & 0.0000 & 0.0719 & 5 & 0.0079 \\
\hline & 2014 & 0.7490 & 14 & 0.1429 & 0.0000 & 0.0672 & 3 & 0.0076 \\
\hline & 2013 & 0.8765 & 13 & 0.1538 & 0.0000 & 0.0768 & 5 & 0.0133 \\
\hline & 2012 & 1.0684 & 14 & 0.0000 & 0.0000 & 0.1062 & 5 & 0.0103 \\
\hline & 2011 & 1.7899 & 21 & 0.0000 & 0.0952 & 0.1844 & 5 & 0.0170 \\
\hline & 2010 & 3.2898 & 22 & 0.0000 & 0.0909 & 0.0979 & 3 & 0.0186 \\
\hline & 2009 & 1.9845 & 22 & 0.0000 & 0.0909 & 0.0792 & 3 & 0.0132 \\
\hline & 2008 & 1.7319 & 14 & 0.0000 & 0.1429 & 0.2688 & 3 & 0.0122 \\
\hline & 2007 & 2.1266 & 13 & 0.0000 & 0.3077 & 0.1131 & 3 & 0.0120 \\
\hline \multirow{10}{*}{$\begin{array}{l}\text { Nationa } \\
1 \text { Credit } \\
\text { and } \\
\text { Comme } \\
\text { rce } \\
\text { Bank } \\
\text { Ltd. }\end{array}$} & 2016 & 0.6727 & 15 & 0.1333 & 0.0667 & 0.1583 & 5 & 0.0130 \\
\hline & 2015 & 0.5134 & 15 & 0.1333 & 0.0667 & 0.1175 & 5 & 0.0097 \\
\hline & 2014 & 0.6267 & 15 & 0.1333 & 0.0667 & 0.1029 & 5 & 0.0116 \\
\hline & 2013 & 0.7554 & 15 & 0.1333 & 0.0667 & 0.1059 & 5 & 0.0091 \\
\hline & 2012 & 1.0425 & 14 & 0.0714 & 0.0714 & 0.1412 & 4 & 0.0114 \\
\hline & 2011 & 1.5593 & 26 & 0.0385 & 0.1154 & 0.1294 & 5 & 0.0212 \\
\hline & 2010 & 3.3096 & 27 & 0.0370 & 0.1154 & 0.1550 & 3 & 0.0284 \\
\hline & 2009 & 2.2075 & 27 & 0.0370 & 0.0741 & 0.2122 & 3 & 0.0261 \\
\hline & 2008 & 1.5863 & 14 & 0.0000 & 0.1429 & 0.1489 & 3 & 0.0154 \\
\hline & 2007 & 1.5492 & 14 & 0.0000 & 0.2143 & 0.1072 & 3 & 0.0159 \\
\hline \multirow{10}{*}{$\begin{array}{c}\text { Prime } \\
\text { Bank } \\
\text { Ltd. }\end{array}$} & 2016 & 0.7203 & 19 & 0.1579 & 0.1579 & 0.2716 & 5 & 0.0086 \\
\hline & 2015 & 0.7030 & 19 & 0.1579 & 0.1579 & 0.2529 & 5 & 0.0084 \\
\hline & 2014 & 0.8207 & 20 & 0.1500 & 0.2500 & 0.2192 & 5 & 0.0096 \\
\hline & 2013 & 1.1413 & 20 & 0.1500 & 0.2500 & 0.1832 & 5 & 0.0076 \\
\hline & 2012 & 1.6517 & 20 & 0.1500 & 0.2500 & 0.2012 & 5 & 0.0124 \\
\hline & 2011 & 1.7974 & 21 & 0.0476 & 0.2381 & 0.2095 & 5 & 0.0205 \\
\hline & 2010 & 3.1240 & 20 & 0.0500 & 0.3000 & 0.2062 & 3 & 0.0222 \\
\hline & 2009 & 1.9763 & 16 & 0.0625 & 0.3125 & 0.1495 & 3 & 0.0237 \\
\hline & 2008 & 0.2292 & 14 & 0.0714 & 0.3571 & 0.1394 & 4 & 0.0130 \\
\hline & 2007 & 0.3986 & 14 & 0.0714 & 0.3571 & 0.1065 & 4 & 0.0199 \\
\hline \multirow{10}{*}{$\begin{array}{c}\text { Pubali } \\
\text { Bank } \\
\text { Ltd. }\end{array}$} & 2016 & 0.8618 & 15 & 0.1333 & 0.1333 & 0.2404 & 5 & 0.0042 \\
\hline & 2015 & 0.7645 & 15 & 0.1333 & 0.0667 & 0.2264 & 5 & 0.0101 \\
\hline & 2014 & 0.9821 & 15 & 0.1333 & 0.0667 & 0.2497 & 5 & 0.0124 \\
\hline & 2013 & 1.3420 & 16 & 0.1250 & 0.1250 & 0.2609 & 5 & 0.0110 \\
\hline & 2012 & 1.4714 & 16 & 0.1250 & 0.1250 & 0.2607 & 4 & 0.0091 \\
\hline & 2011 & 1.9560 & 15 & 0.0667 & 0.0667 & 0.2083 & 5 & 0.0210 \\
\hline & 2010 & 3.7109 & 14 & 0.0000 & 0.0714 & 0.3876 & 3 & 0.0244 \\
\hline & 2009 & 2.5100 & 14 & 0.0000 & 0.0714 & 0.2455 & 3 & 0.0194 \\
\hline & 2008 & 2.1154 & 14 & 0.0000 & 0.0714 & 0.4168 & 3 & 0.0168 \\
\hline & 2007 & 1.9647 & 13 & 0.0000 & 0.0769 & 0.2396 & 3 & 0.0189 \\
\hline
\end{tabular}




\begin{tabular}{|c|c|c|c|c|c|c|c|c|}
\hline \multirow{10}{*}{$\begin{array}{c}\text { Trust } \\
\text { Bank } \\
\text { Ltd. }\end{array}$} & 2016 & 0.9985 & 12 & 0.2500 & 0.0000 & 0.2111 & 4 & 0.0103 \\
\hline & 2015 & 1.1878 & 11 & 0.2727 & 0.0000 & 0.2106 & 4 & 0.0085 \\
\hline & 2014 & 0.7303 & 10 & 0.3000 & 0.1000 & 0.2150 & 3 & 0.0089 \\
\hline & 2013 & 1.0570 & 10 & 0.3000 & 0.1000 & 0.2040 & 4 & 0.0028 \\
\hline & 2012 & 1.2626 & 9 & 0.2222 & 0.1111 & 0.2315 & 5 & 0.0019 \\
\hline & 2011 & 1.9470 & 9 & 0.1111 & 0.1111 & 0.2113 & 4 & 0.0081 \\
\hline & 2010 & 3.3110 & 9 & 0.0000 & 0.1111 & 0.1951 & 3 & 0.0227 \\
\hline & 2009 & 2.1360 & 8 & 0.0000 & 0.1250 & 0.1911 & 3 & 0.0132 \\
\hline & 2008 & 2.1967 & 10 & 0.0000 & 0.1000 & 0.1203 & 3 & 0.0120 \\
\hline & 2007 & 5.0324 & 8 & 0.0000 & 0.1000 & 0.1402 & 3 & 0.0079 \\
\hline \multirow{10}{*}{$\begin{array}{c}\text { United } \\
\text { Comme } \\
\text { rcial } \\
\text { Bank } \\
\text { Ltd. }\end{array}$} & 2016 & 0.8717 & 20 & 0.1500 & 0.1000 & 0.1286 & 5 & 0.0084 \\
\hline & 2015 & 0.8357 & 20 & 0.1500 & 0.1000 & 0.1415 & 5 & 0.0142 \\
\hline & 2014 & 1.0899 & 20 & 0.1500 & 0.1000 & 0.1938 & 4 & 0.0149 \\
\hline & 2013 & 1.0241 & 19 & 0.2105 & 0.1053 & 0.0493 & 4 & 0.0141 \\
\hline & 2012 & 1.0866 & 16 & 0.0000 & 0.1250 & 0.1141 & 4 & 0.0084 \\
\hline & 2011 & 2.0002 & 23 & 0.0000 & 0.0870 & 0.1268 & 5 & 0.0174 \\
\hline & 2010 & 8.4397 & 23 & 0.0000 & 0.1304 & 0.0413 & 3 & 0.0168 \\
\hline & 2009 & 1.6729 & 14 & 0.0000 & 0.2143 & 0.0000 & 3 & 0.0103 \\
\hline & 2008 & 2.1770 & 14 & 0.0000 & 0.2143 & 0.0000 & 3 & 0.0118 \\
\hline & 2007 & 4.0092 & 19 & 0.0000 & 0.1579 & 0.0000 & 3 & 0.0162 \\
\hline \multirow{10}{*}{$\begin{array}{c}\text { Uttara } \\
\text { Bank } \\
\text { Limited }\end{array}$} & 2016 & 0.7402 & 15 & 0.2000 & 0.0000 & 0.2639 & 5 & 0.0094 \\
\hline & 2015 & 0.6903 & 14 & 0.2143 & 0.0000 & 0.1820 & 4 & 0.0099 \\
\hline & 2014 & 0.8508 & 14 & 0.2143 & 0.0000 & 0.1472 & 3 & 0.0099 \\
\hline & 2013 & 1.0592 & 14 & 0.2143 & 0.0000 & 0.0987 & 3 & 0.0099 \\
\hline & 2012 & 1.2859 & 15 & 0.1333 & 0.0667 & 0.1444 & 3 & 0.0100 \\
\hline & 2011 & 2.3219 & 15 & 0.0000 & 0.0667 & 0.0865 & 3 & 0.0169 \\
\hline & 2010 & 4.6212 & 14 & 0.0714 & 0.0000 & 0.0319 & 3 & 0.0191 \\
\hline & 2009 & 3.7323 & 15 & 0.0667 & 0.0000 & 0.0423 & 3 & 0.0154 \\
\hline & 2008 & 7.3478 & 14 & 0.0714 & 0.0000 & 0.0790 & 3 & 0.0195 \\
\hline & 2007 & 7.9014 & 14 & 0.0714 & 0.0000 & 0.0634 & 3 & 0.0077 \\
\hline
\end{tabular}

Online Archive: https://abc.us.org/ojs/index.php/abr/issue/archive 